\title{
Some Observations on the Appraisal of Kəbrä Nägäst
}

\author{
Melakneh Mengistu \\ Addis Ababa University, Addis Ababa, Ethiopia
}

\begin{abstract}
The Zagwe period is believed to be the richest and most artistic period of Ethiopian civilization since the conversion of Ezana though its achievements have been virtually consigned to obscurity. One of the ideological weapons which aggravated its obscurity is arguably the deep-rooted allegiance of the Kəbrä Nägäśt to the Solomonic Dynasty. Contemporary researchers on Kəbrà Nägàśt seem to have underestimated the ideological onslaught of the Kəbrä Nägäśt on the Zagwe period that Agäw contribution to the medieval Ethiopian civilization has been virtually shrouded in mystery. Thus, expatriate and compatriot authorities on the medieval Ethiopian cultural history are called upon to demystify the obscurity of the Zagwe period, thereby, to reconstruct the unsung contributions of Agäw civilization with intellectual profundity and inquiry.
\end{abstract}

Keywords: Kəbrä Nägäśt, Agäw civilization, critical observations, obscurity, historical reconstruction, intellectual profundity

\section{The Historical Background and Acculturation of Agäws}

Northern, central and north-western Ethiopia is inhabited by the Amhara, the Tigre, and the Agäw people, who are hardly distinguishable from one another. These groups have many common cultural, historical, geographical roots and somatic characteristics (Gamst, 1984, pp. 11-12). Agäw is a generic name with which four well-known Cushitic speaking groups of Ethiopia spread over Eritrea and north-western Ethiopia are designated. They are the most ancient and indigenous people of Ethiopia. "The Agäw, indeed, were the very basis on which the whole edifice of Axumite civilization was constructed. In later times, the Agäw remained a key linguistic, ethnic, and cultural component in the formation of Tigrean, and especially, Amhara civilization (Taddesse, 1988, pp. 6-7; Quirin, 1998, pp. 197-198).

Regarding their geo-physical setting, Taddesse Tamirat asserted that,

The Agäw were the inhabitants of the country north of Jäma and east of the Abbay. He further maintains that at the medieval period, the Agäw language and people consisted of a number of island-like survivals spread over a great territory extending from Bogos in Eritrea to Agäw-Mədr in Goĝgam and to the areas east and south of the Bäshillo River which formed the emerging region of Amhara. (Taddesse, 1972, p. 5)

In his recent study, Taddesse also reiterated that the scattered survivals are as wide spread as Kärän; (Eritrea), Quara; (Sämen Gondär Zone), Agäw-Mədr Goĝĝam and Wag-Həmra Administrative Zone of the Amhara Region (Taddesse, 1988, p. 5).

Similarly, Levine asserted that "During the first millennium A.D., the inhabitants of Amhara were the Agäw people who developed a distinct South-Ethio-Semitic tongue-Amharic-quite possibly through a process

Melakneh Mengistu, Ph.D., Asst. Professor of Post-Colonial Literature, Department of Foreign Languages and Literature, Addis Ababa University. 
of pidginization and creolization" (Levine, 1973, p. 72). In the same vein, Buxton presumed that the area under the direct rule of the Zagwe kings "probably embraced the highlands of modern Eritrea and the whole of Tigray extending southwards to Wag, Lasta, and Damot and thence westwards towards Lake Tana" (Buxton, 1970, p. 44). Thus, different sections of the Agäw seem to have constituted an important part of the population occupying the highland interior of northern and central Ethiopia since time immemorial.

According to Taddesse, "The exact process of this development cannot be reconstructed for those early days. But this kind of interaction could be attributed to internal strife, migration or resettlement venture" (Taddesse, 1988, p. 5). Traditional historians like Taye, however, do not recognize the black Jews as an ethnic Agäw on account of their Hebraic practices or Jewish faith which is incompatible with the monotheistic Orthodox Christianity (Taye, 1946, p. 18) and from which the Amhara-Tigre tradition is not still liberated.

Regarding the state of their language, Hetzron maintained that:

The Agäw language was once spoken in a very large area in the northern half of Ethiopia but was gradually superseded by Semitic languages like Amharic and Tigriňa. The once continuous Agäw areas are split into small islands that have so far escaped Semitization. (Hetzron, 1969, p. 2)

For instance, the Agäw language has been superseded by Amharic in the northern half of Ethiopia ever since the fifteenth century which marks the emergence of Amharization which is to be understood as the prevalence of Amharic over the Agäw languages like Awgni; (southern Agäw); Billän; Eritrea, Xhamtanga, and Wällo (Wag-Säqoța). This aspect of acculturation is also applicable to Tigreanization in which case many Agäws in the neighborhoods have been virtually assimilated. This is partly attributed to the unholy alliance of the clergy with the so-called Solomonic Dynasty. Accordingly, Mäşəhäfä R'tuz or the book of orthodoxy abounds with anti-Zagwe stereotypes). For instance, one of their Satanic verses directed against the Agäw people and the Agäw language reads in $G e^{\prime} e z^{2}$ reads:

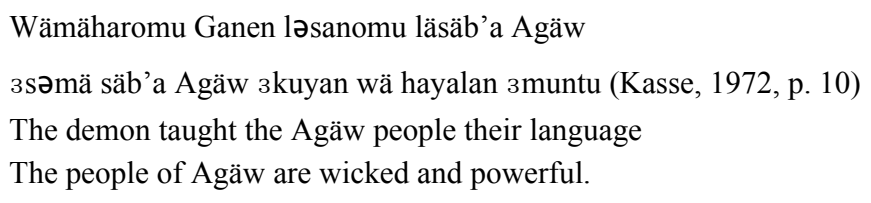

One can imagine how incredibly such stereotypes could easily mislead the gullible minds of those days at an age when anything in $G \partial^{\prime} \partial z$ was taken for granted to be of a Divine origin mainly by the clergy and by the congregation. By the same token, Dästa Täklä-Wold (1992), an Ethiopian Lexicographer, defined Agäwňa as:

Yä Agäw qwuanquwa; Agäwoर yäminagärut..Qesoćçäw 3ndä Tigrena

Amara bä Ge-ez yäqädəsalu

A language spoken by ethnic Agäw; their priests conduct holy masses in Ge'ez like Amhara and Tigrean priests stigmatizes their human language by identifying it with the birds' medium of communication as

Yä Agäw säw yäwäf qwuanquwa yawuqal yəlalu

It is presumed that the Agäws are conversant with the language of birds.

\footnotetext{
${ }^{1}$ Lake Tana is the largest lake In Ethiopia lying between Goğğam and Gondär which are the heartlands of Amhara National Regional State inhabited by the Amhara, Agäw, and Qəmant ethnic groups to date.

${ }^{2} G e^{\prime} e z$ is a classical Ethiopian language from which Amharic is said to have gradually evolved and is confined to liturgical services.
} 
It is intended to comment on its 'unintelligibility' by the standards of Ge'ez or Amharic. It is rather a reflection of the deep-rooted prejudice against the Agäw people and their language, thereby, glorifying Gə'əz and stereotyping Agäwəňa. Who could be held more responsible than the Solomonic elite for the current ethnic polarization and identity crisis in Ethiopia? (Dästa Täklä-Wold, 1992, p. 79)

When it comes to its variants, Appleyard (1988, p. 581) has classified Central Cushitic into four distant dialects as under:

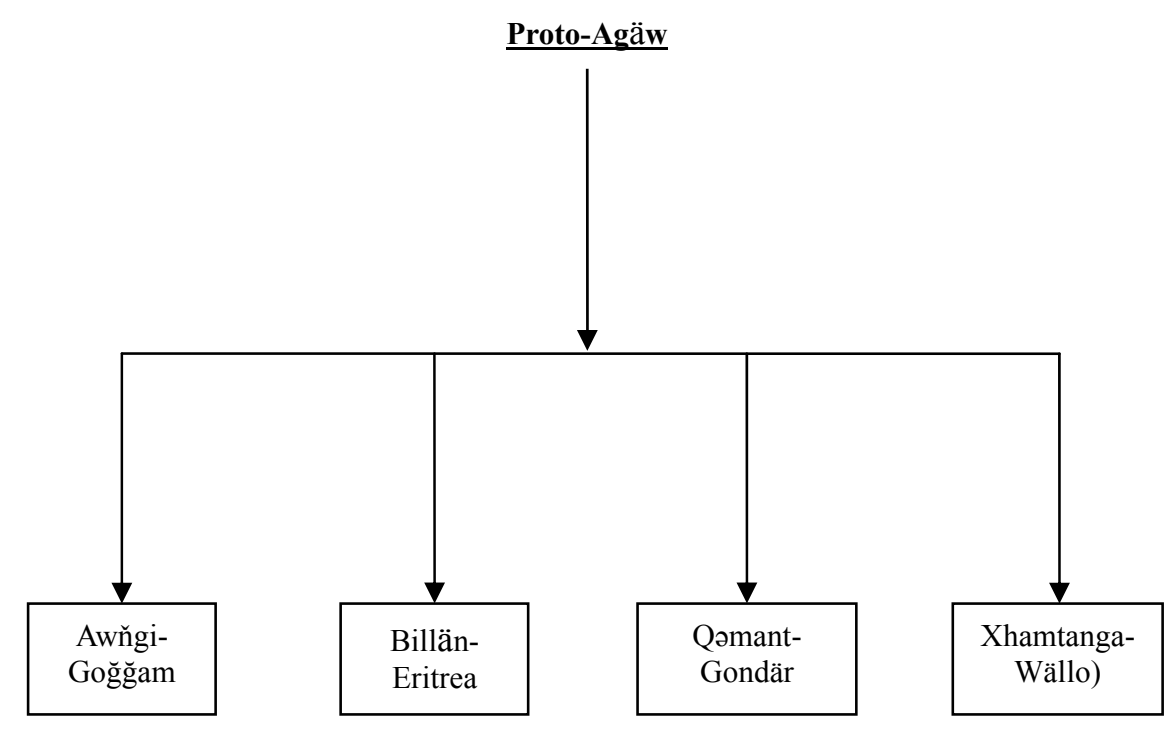

These languages are said to be mutually unintelligible due to a prolonged isolation and hence descriptively almost independent. The long-term effect of such isolation from each other and the irresistible cultural assimilation into Amharization and Tigreanization has been the supersession of their languages. Consequently, the Agäw in and around Kärän; Wällo, Gondär, Goĝĝam and some parts of Tigray have formed island-like survivals in terms of the retention of their vernacular which provides the weakest social boundary with the neighboring Semites whose culture and physiognomy are indistinguishable from one another (Gamst 1984).

Presently, the Agäw speaking families across the pocket survivals are apparently dwindling due to the growing pressures of urbanization, demographic shifts like rural migration and the striking cultural congruence between the two groups. This problem was compounded by the prolonged reign of the Solomonic Dynasty and the hospitality and healthy attitude of the Agäw towards Amhara ethnic group and vice versa. Gamst in this regard asserted that,

Amharization has not and probably will not affect the various other ethnic groups of Ethiopia as drastically as it has affected the Agäw... The reason why most Agäw groups have been so effectively Amharized to the point of total assimilation is that they have had a continuous contact with the Amhara over a span of many centuries, and their acculturation has been further encouraged by congruence between the two cultures. (Gamst, 1984, p. 124)

This assertion is also equally applicable to the Tigreanization of Agäw residing the vicinities of Tigray. Such an effective assimilation has already resulted in the dwindling number of Agäwňa speakers from millions to hundred thousand across north-western Ethiopia. A case in point is the Agäws of Agäw-Mədr, Goĝgam; Kärän, Eritrea; Wag-Säqoța and Abärgäle; Northern Wällo, and some pocket survivals in and around Gondär, Tigray; Tämben who speak Amharic or Təgriňa with an Agäw bent. Fəqre (1993, p. 8) and Fiqəre (2008, pp. 
245-246) also maintained that Amharic emerged in the breast of the Zagwe Dynasty as a Lassanä Nagus or the chosen tongue of the Imperial Court thus marking the origin of Amharization.

\section{Objectives and Methods of the Study}

The historiography of Ethiopian political history is predominantly influenced by the idiosyncrasies of contemporary chroniclers or personalities. One of these chronicles was the Kəbrä Nägäśt which had captured the attention of many compatriot and expatriate scholars since its appearance and dissemination. These scholars whose list is inexhaustible for space and time have produced commendable research outputs on the content, motives, form, and aesthetic value of this "National imaginary". However, its reception and popularization appears to be biased for the Solomonic Dynasty while its adverse impact on the socio-cultural and architectural achievements of the Zagwe period is virtually shunned away.

This study was designed to determine the extent to which studies on the Kabrä Nägàśt are justifiable or objectionable on account of their partisanship or degree of objectivity. Thus, the corpus of literature on this master code could be viewed from the other end of the telescope in spite of its popularity. To that effect, accessible studies on the work would be critically examined with a view to discovering the gaps and lapses in its appraisal.

This is intended to reconstruct what has gone wrong in the "who is who" of Ethiopian history and unravel the mysterious obscurity of the Zagwe period, and thereby, to provoke an inter-disciplinary research from an alternative perspective by way of revisiting it or expanding its horizon with a view to discovering the unsung achievements of the Zagwe civilization but not to undermine the literary, historical, and theological significance of the Kəbrä Nägäst.

Regarding methods of the study, it involves document analysis or descriptive criticism. Procedurally, a closer reading of the text itself would be followed by the description, assimilation, and interpretation of its content and form.

Secondly, studies on the text ranging from book reviews to full-fledged journal articles, published books, and microfilms are critically reviewed in the context of the power struggle between the Solomonic and the Zagwe Dynasties including their attendant propaganda and counter-propaganda. What matters most here is identifying the perspective from which the scholars in question have examined, rated, validated, and endorsed the Kabrä Nägàśt objectively or impressionistically with all its implications for the mystification of Zagwe contribution to the medieval Ethiopian Civilization.

\section{The Zagwe Period vs. the Colophon of Kəbrà Nägàśt}

The decline of the Axumite Kingdom brought about a period of Agäw ascendancy and political control of Ethiopia and the establishment of the Zagwe Dynasty (C. 10th AD). Zagwe designates one of the oldest dynasties which ruled Ethiopia after the decline of the Axumite Kingdom (Gamst, 1984; Ullendorff, 1965).

There are two conflicting sources - internal and external — regarding the chronology of the Zagwe Dynasty. To begin with, Taddesse limited the rule of the Zagwe to 130 years (1140-1270) on the basis of established earlier scholarship and other documents.

Similarly, Gamst maintained that the Zagwe rule lasted 170 years (1100-1270 AD) and 133 years (1137-1270) respectively. According to Ethiopian sources, most of which were compiled from the late fifteenth century onwards, the Zagwe Dynasty began in the first half of the tenth century or C. 930 AD. For instance, 
Aläqa (Chief) Tayyä maintained that the Zagwe came to power in the first half of the tenth century.

The Zagwe are, therefore, supposed to have ruled the country for a period of three centuries. Other Ethiopian sources limit the number of kings to five, thereby supporting the argument put forward by Conti Rossini (1928) that the Zagwe could not have ruled more than a century and a half. Sergew (1972a), on the basis of fragmented Coptic and Arabic sources, argued that the Zagwe probably came to power between 1030 and $1050 \mathrm{AD}$ thus reducing the Zagwe period from the maximum 375 years to slightly over 200 years. The reason behind this kind of inconsistency could be attributed to the lack of documentary evidence lending credence to the facts and figures surrounding the myth of the Zagwe Dynasty.

Thus, it seems that no consensus has been reached among scholars on the chronology of the Zagwe Period. At any rate, the Agäw rule over Ethiopia, whether consolidated or shaky, seems to have spanned over a century as could be recovered from oral tradition and multifarious documents.

One of the problems surrounding the study of the Kəbrä Nägäst is its colophonic inconsistency. The facts of its publication such as the anonymity of its compilers, the date of its appearance, its source (indigenous or a translation from Coptic legends), and the circumstances under which it was composed remain dubious. With regard to the setting, Carl Bezold has marked off the date of its compilation to the post-restoration period of the Solomonic line with the advent of Yəkunno Ámlak to the throne (1270-1285) though he does not locate a specific date (Bezold, 1928, p. 12; Assefa, 2007, pp. 44-45).

Taddesse's argument that the first Arabic copy of the book was translated from the Coptic manuscript in 1225, in the days of Lalibälla and Abba George, The Good Bishop in Ethiopia is consistent with the Arabic version of the colophon. He further noted that the anti-Zagwe feelings among the Semitic-speaking Christians-Tigre and Amhara - are provided by the tradition about the first Arabic copy of the Kəbrä Nägäśt in Ethiopia. An Ethiopian Version could not be made right away because as the scribe has it; it went out in the days of Zagwe and they did not translate it because this book says;

3səmä wäşä at bämäwa3lä Zagwe səmä təbəl zati mäşəhaf 3läs yənägəsu 3la 3konu Israel tä'adəwo həg wu'stu.

That book appeared during of the reign of the Zagwe for it forbids those who reign, not being Israelites, as transgressors of the Law. (Taddesse, 1988, p. 65)

Yonas, on the other hand, argued that it does not matter whether the exact date of the compilation of the Ethiopic version of the Kəbrä Nägäśt is located or not, but its reflection of the socio-political context. What matters most, according to Yonas (1995), is "the general period - as an indicator of the cultural political or the ideological atmosphere as a condition sine qua non of the work's production" (p. 49).

Thus, the relevance of Ullendorff's observation that "the period in question" was one of those critical moments in the history of the country marked by power struggle between the Zagwe Dynasty and the so-called Solomonic Dynasty (Ullendorff, 1965, p. 4). Though its facts of publication remain to be contentious, it could be safely concluded that the book must have been compiled by proponents of the Solomonic Dynasty and popularized during the power struggle between the Zagwe and the former. In this context, the colophon of its appearance seems to be by no means accidental. By implication

Ethiopia appears to have been a powerful country on the Horn of Africa during Emperor Lalibälla's time. This claim (sic) might have driven some of their antagonists... to wage an anti-Zagwe war of propaganda that might have contributed to their down fall. (Bayä, 1996, p. 6) 


\section{The Solomon-Sheba Myth}

The Semitic Ethiopians and the Agäw are known to have experienced a bloody power struggle against each other, as well as, instances of peaceful transitions from one Dynasty to another. The overthrow of the Zagwe Dynasty or the restoration of the neo-Solomonic Dynasty in 1270 is presumably attributed to the concerted intrigues of the clergy and the neo-Solomonic elite on ideological grounds. The Zagwe were allegedly believed to be illegitimate to the throne in the traditional Ethiopian theocracy that the neo-Solomonic Dynasty had regarded the Zagwe Dynasty as usurpers of the throne.

One of the propaganda ploys devised to disparage the Zagwe, among other things, was the production and dissemination of the Kəbrä Nägàśt by the clergy and the proponents of the Solomonic Dynasty. Among a range of sources, Jack provided a brief summary of its contents as follows:

The heart of the work tells of the queen of Saba's visit to King Solomon, her infatuation with him, and his wisdom and wealth; her conversion to Judaism, her marriage to him; her return to Ethiopia the birth of their son, Menelik, the subsequent visit of Menelik to Solomon - his father, the removal of the Ark of the Covenant from Israel to Ethiopia, the African Zion and its enshrining in Axum-the new Jerusalem-the rule of king Menelik I, the second David, over Ethiopia, and the establishment of a messianic Dynasty. (Jack, 1996, p. 192)

According to Rank (1959) and Budge (1922), the saga of such a legendary hero is also characterized by the following elements:

(1) The hero is the son of the most distinguished parents;

(2) His origin is preceded by difficulties, such as secret intercourse of parents due to external prohibitions;

(3) During or before pregnancy, there is a prophecy in the form of dream or oracle cautioning against his birth, and usually threatening danger to the father;

(4) As a rule, he is saved by animals or lowly people;

(5) After he is grown up, he finds his distinguished parents in a versatile fashion;

(6) He takes revenge on his father;

(7) He achieves rank and honor (Rank, 1959, p. 65; Levine, 1973, p. 18).

On the bases of the above parameters, Levine contended that Menelik I is more like a legendary figure than an historical monarch as he exhibits the characteristic features of Oedipus the King ${ }^{3}$. In fact, neither Solomon nor Saba or Menelik was supernatural but ordinary mortals.

By implication, the foundation of an ancient Ethiopian empire which enjoyed unshakable political, diplomatic, economic, and cultural ties with Jerusalem is a tribute to medieval monarchs and their chroniclers who produced a political gospel to that effect. On the other hand, their legendary journey to Jerusalem seems to be more like a diplomatic mission rather than a heroic venture involving high risks. It then follows that the Kəbrä Nägäśt is believed to be a politically motivated myth evolved by the pro-Solomonic elite.

It is widely believed that the Kəbrä Nägàst was politically motivated apart from its theological and historical concerns. Most importantly, it was employed as strong weapon of political fortification or as an exclusive political gospel of those days. Thus, Hubbard asserted that,

To fortify the claims of Yəkunno Ámlak, his successors' unbroken line to the last monarch, it was necessary to set down in a systematic fashion, the Axumite tradition of the Semitic descent of the ruling family. (Hubbard, 1956, p. 15)

\footnotetext{
3 The title-hero Sophocles' play dating back to the BC's. It is a classical tragedy which relates the story of an ill-fated prince who unwittingly kills his father and marries his mother in accordance with the Prophecy of Apollo.
} 
This argument has also been reinforced by Piovanelli and others who share the views of Hubbard unequivocally:

The Kəbrä Nägäśt was written to justify the claims of the so called Solomonic Dynasty founded by Yəkunno Amlak over the Zagwe family who had held sway for well over a century. The major ideological aim of the Kəbrä Nägäśt is thus evident to establish the moral authority of the new royal Dynasty founded by Yəkunno Amlak (1270-1285) by presenting the arrival to power of the new southern, Amharic speaking military leaders not as a revolution but as a timely restoration after centuries of trouble and usurpation. (Piovanelli, 2013, pp. 9-10; Hubbard, 1956, p. 360)

By the same token, Levine endorsed Conti Rossini's view who categorically stated that the "Kəbrä Nägäśt has no other purpose than that of demonstrating the usurpation of Yəkunno Ámlak to be nothing more than a just act of vindication" (Levine, 1975, p. 12).

The Kəbrä Nägäśt has apparently integrated most of the basic beliefs of Ethiopian tradition into a consistent ideological scheme, which is dramatized through the Solomon-Saba myth in the sense of ideological construct. According to the Kəbrä Nägäśt, it is ordained that "no one except the male seed of David, the Son of Solomon the King, shall ever reign over Ethiopia" (Budge, 1922, p. 127).

Thus, the victory of the Solomonic line over the Zagwe Dynasty was accompanied by a concerted ideological campaign by the Church and State with accent on the "restoration of the Solomonic Dynasty".

Ever since the introduction of Christianity to Ethiopia in the fourth century, the Church has been closely related to the state. In other words, the Church was dependent on the kings for its material needs, while the ruling elite needed the Church to legitimize its rule. This intimate collaboration between the Ethiopian State and Church was to a great extent the reason for the evolution and maintenance of the national saga of the Solomonic origins of the Ethiopian ruling house and of the "Jewish origin of the Ethiopian population" first developed in the first half of the sixth century. Bayä also conjectured that,

Ethiopia appears to have been a powerful country on the Horn of Africa during Emperor Lalibälla's time. This claim (sic) might have driven some of their antagonists... to wage an anti-Zagwe war of propaganda that might have contributed to their down fall. (Bayä, 1996, p. 6)

During the power struggle between both dynasties, the Anti-Zagwe moves were spearheaded by the so-called saints and monastic scribes like Ábunä (Bishop) Täklä Haymanot of Šäwa and Yäsus-Mo'a of Däbrä Damo. Some of their sermons intended for the congregation under the guise of evangelization were characterized by the patronage of the Church in political affairs as reflected in the following couplet which borders on a Propaganda ploy:

Wätähaydät mänəgəst wätä wuhəbät läkala’n

3la 3konu 3məhəzəbä Israel zaw 3tomu Zagwe. (Roth, 1905, p. 172; Gädlä Täklä Haymanot, 1946, p. 28)

The state power was usurped by others who are non-Israelites; They are the Zagwe.

By the same token, Assefa with a cross-reference to Gäbrä Səlasse, who was the chronicler of Mənelik II, also recapitulated the myth of the Solomonic Dynasty which was intent upon marginalizing the non-Solomonic elements from political power and the role of Täklä Haymanot in the restoration process:

Yä Israel mänəgəst ...Israel laydälu.. läloर́ säwoć täsäțäć..

3näzihəm Zagwe yəbalalu..333 amät nägäsu.. Yä Israel mänəgəst 
kä Israel lätäwälädä lä Yəkunno Amla babataćən babunä Täklä Haymanot şälot Egziabher mäläsälät. (cited in Assefa, 2007, pp. 125-126)

The State of Israel was transferred to the others who are non-Israelites. These are known as the Zagwe. They ruled for 333 years. God restored the power to Yakunno Amlak who descends from the line of Solomon with the help of Abuna Täklä Haymanot's prayer.

This is an indication of the propaganda warfare waged against the Zagwe by the adherents of the so-called Solomonic Dynasty with "divine" intervention. It must have been cherished for strategic reasons up until the eve of the February Revolution of 1974 which dealt a decisive blow to the legendary Dynasty. Otherwise, there could be no divine ordinance in favor of the Solomonic line or against the Zagwe Dynasty which is politically, morally, and theologically motivated.

Although the Zagwe rulers were, on the whole, more devout than the Solomonic rulers, they did not achieve ideological legitimacy due to the concerted intrigues of the clergy and the Solomonic elite. The Monotheistic Christianity and the Monarchy were the principal pillars of Ethiopia till the breakout of the February Revolution (1974) which brought an abrupt end to the feudal order in Ethiopia. Church and State have thus been operating hand-in-glove ever since the restoration of the Solomonic Dynasty with Yəkunno Ámlak (1270).

According to historians like Budge (1922) and the bulk of oral tradition, the last king of the Zagwe Dynasty, Nä'akuttolä'ab, abdicated peacefully in favor of Yəkunno Amlak at the instance of Abunä Täklä Haymanot, though such an assertion does not seem to stand to reason in the context of power struggle. Similarly, Bayä asserted that, "The majority of historians like Donald Levine, usually disparage the Zagwe rulers as usurpers, the reason among others for saying so being that Märra Täklä Haymanot had defeated the Axumite Emperor in battle" (Bayä, 1996, p. 40). This joint offensive unleashed by the anti-Zagwe elite was intended to brainwash the generality of the public and instill the legitimacy of Yəkunno Ámlak in particular and the Solomonic Dynasty in general.

The anti-Zagwe campaign through it which was propagated includes both regular sermons intended for the congregation and the dissemination of manuscripts like the Kəbrä Nägäśt (Glory of Kings). Consequently, the Solomonic Dynasty used to enjoy this political prestige without interruption right from Yəkunno Ámlak down to Haile Śelasse I (1270-1974) nearly for seven centuries.

From the foregoing observations, it could be concluded that the scribes of those days were not only mere sycophants but also politicians in disguise. The Kəbrä Nägäśt thus provided the ideological justification for the process of Semitic expansion and defined the criteria for assimilation into Orthodox Christianity and acculturation. Consequently, one-third of the government revenue since the reign of Yəkunno Amlak down to Haile Selasse I had to go to the Church in return for its outstanding contribution to the concerted coup: Hubbard reflected upon this intrigue as follows:

There appeared a member of the Solomonic line called Yekunno-Amlak in Shoa, and with the help of the greater Saint, Abunä Täkəlä Haymanot, he expelled the Zagwe and became King of Kings of Ethiopia. In return for his help of the Saint, Yəkunno Amlak agreed to give to Church one-third of the revenue of his kingdom, and his successors have followed, on the whole, his example. (Hubbard, 1956, p. 362)

Thus, the scribes s of Kəbrä Nägàśt were not motivated by artistic pursuits as the Solomonic elite would have us believe but politicize the restoration process. The clergy, for instance, resided at court and followed the 
emperor in his wanderings throughout the country. Though there were doctrinal differences among Ethiopian clergy, some of them seeking the support of secular power were no doubt instrumental in the consolidation of the Solomonic line. In connection with its theological concern, Budge asserted that,

The Kəbrä Nägàśt was edited to make the people of Ethiopia believe that their country was especially chosen by God to be the new home of the spiritual and Heavenly Zion of which its chosen people the, Jews, had become unworthy. (Budge, 1922, p. 13)

This dream was traditionally associated with the theft of the Ark of the Covenant (Şallatä Muse) or associated with the Biblical Moses. It follows that the theosophical conception of the link between Judaism and Ethiopian Orthodox Church made Christianity a prime integrating force in the life of the society.

Many historians like Hubbard (1956) and Levine (1974) maintained that the historic bond which unified Christianity, the Ethiopian nation, and the Solomonic Dynasty has traditionally been so significant that it seemed faith; nation and throne are linked by Divine ordinance. Thus, scholars like Piovanelli endorsed the view that the Käbrä Nägäst was a strong theological weapon which fortified the Solomonic descent of Ethiopian kings from Menelik I to the deposition of Haile Selasse I in 1974:

The Käbrä Nägäst provided Ethiopian Christianity with a strong and lasting Israelite identity that eventually enabled its rulers to negotiate as equals with their European homologues and even, in the case of Emperor Haile Selasse I to be perceived as the black messiah of the African people in exile. In this sense, the Käbrä Nägäst functioned as a means to establish a new political, social, and religious order. (Piovanelli, 2013, pp. 20-21)

\section{The Reception of Kəbrà Nàgàśt Under the Ethiopian Monarchy}

The Kəbrä Nägàśt is a national epic in three respects: First, it contains a myth of the founding of the Ethiopian nation which is an imaginative work that embodies a conception of crucial formative events in the national history. Second, it can be interpreted as an expression of central psychological conflicts which members of the society typically experience in the course of growing up. Third, it is a literary expression of a complex of constitutive symbolism or cultural legitimacy (Levine, 1975, p. 16).

All the more, Yonas corroborated Levine's view with the following assertion:

Kəbrä Nàgàśt is a national epic in the sense that it is a foundational narrative ... which edifies and glorifies the foundation of the Ethiopian Empire by deliberately connecting its founding to some prestigious past, and further describes it as a "master code" for it was employed as a means of creating a viable national identity. (Yonas, 1995, p. 56)

It could also be classified as myth which is a traditional story that ostensibly explains the genesis of social or natural phenomena. Mythology serves an etiological function and entails a moral or political sanction. Mythological stories seem to retain their power and attraction over thousand years of history since they appeal to some basic instinct in humans as is the case with the Kəbrä Nägäśt by which the superiority complex of Semitic Abyssinians has been shaped and cherished as an embodiment of their deep-rooted psychological complex like socio-cultural strings of constitutive symbolism or cultural legitimacy (Levine, 1975, p. 16).

Since the legitimacy of the throne derived from a belief system formulated in religious terms, the authority of the throne had to concern the subject of faith. Consequently, almost all Ethiopian monarchs were loyal to the principles prescribed by the Kəbrä Nägäśt among others.

For instance, Ethiopian Emperors like Yohannes IV and Haile Selasse I are known to have upheld the views stipulated in the Kəbrä Nägäśt. To cite but few examples, Yohannes IV had a high regard for this 
document. This was reflected in one of his letters to the late Lord Granville, the Contemporary Superintendent of the British Museum, in August 1872 demanding the return of the Kəbrä Nägäśt which was plundered by the British army after the heroic fall of Theodros at Mäqdäla $\mathrm{Amba}^{4}$.

An extract from this letter thus reads:

There is a book called "Kivera Negust" which contains the Law of the whole of Ethiopia, and the names of the Shums (i.e., chiefs), and Churches, and Provinces are in this book. I pray you find out who has got this book, and send it to me, for in my country my people will not obey my orders without it. (Hubbard, 1956, pp. 4-5; Shahid, 1976, p. 37)

Similarly, the late Emperor Haile Selasse I had also a similar regard for the book. This was expressed in his exclusive interview with the Editor-In-Chief of The Sunday Dispatch in 1964. In the words of the Editor:

I asked Emperor Haile Selasse I if he would make a personal comment on this legend. He replied in a firm and forthright manner: "This is not a legend. It is based on the most universal book in the world-the Holy Bible". (Hubbard, 1956, pp. 4-5)

Even more so, the claim of Haile Selasse I to have descended from the House of David, which is an expression of a Divine ointment as promulgated in the Revised Constitution of 1955 is yet another justification for the inviolability of the Emperor's power. Thus, it could be concluded that the Kəbrä Nägäśt is a political, theological, and historical manifesto intended to invest an aura of legitimacy to the neo-Solomonic Dynasty. Moreover, this theocracy is highlighted in the (Revised Constitution, 1955, p. 3) follows:

Anqäş Anəd: Yä Ethiopia nəgusä nägäst kä Ethiopia nəgəst kä nəgəstä Sabana ka Eyärusalemu nəgus kä Solomon kätäwälädäw kä Qädamawi Menelik nägäd sayaqwarəț täyäyəzo kämätaw kä nəgus zär kä Qädamawi Haile Selasse təwələd saywäța mən gizem yənoral.

Article One: The imperial dignity shall remain perpetually attached to the line of Haile Selasse I, descendant of King Sahle Selasse, whose line descends without interruption from the Dynasty of Menilik I, Son of the Queen of Ethiopia, the Queen of Saba, and King Solomon of Jerusalem.

Anqäş Arat: Nəgusä nägästu yänäşgasi zär bämähonuna qəbə’a mängəst bämäqäbatu kəbru yämayəqänäs ma'3ragu yämayəgäsäs sələțanu yämayəfärəs.

Hono bäqoyäw ləmədna badisum həg bämigbaw kəbər hulu yəkäbäral.

Article Four: That by virtue of his imperial blood as well as the anointing which he has received, the person of the Emperor is sacred; his dignity inviolable and his power is indisputable.

By virtue of his "divine ordinance" and anointment, the Emperor was also accorded with inviolable dignity and indisputable power. Consequently, the royal title of Emperor Haile Selasse I which was embellished with phrases like "the Conquering Lion of the Tribe of Judah, King of Kings, Elect of God, and Emperor of Ethiopia" is a presumably reassertion of his "royal blood". This kind of political indoctrination was cherished by Semitic Ethiopians as well as the bulk of the populace under the monarchy, at least, up to the breakout of the defunct February Revolution of 1974. Thus, Jack contended that,

\footnotetext{
${ }^{4}$ Mäquədälla Amba, southern Wällo, was Theodora's last stronghold (which was subsequently converted into his treasury and detention camp). It was a strategic point which is about $9000 \mathrm{mts}$. above sea level where Theodros committed suicide.
} 
The Kəbrä Nägäśst is arguably the most outstanding work of Ethiopian literature. The epic and national saga of Ethiopia, it is the very epitome of Ethiopia's national, historical and religious feelings, and has been most intimately woven into the very fabric of Ethiopian life and society. (Jack, 1996, p. 192)

This view is also corroborated with Levine's assertion that the Kəbrä Nägäśt is a repository of the Ethiopian national and religious feelings (Levine, 1975, p. 16).

\section{The Unsung Contribution of Agäws to Ethiopian Civilization}

In spite of its wide-acclaimed reception, the Kəbrä Nägäśt is believed to have cast its shadow over the Agäw Civilization of the medieval Period. The author begs to differ from Bayä who contended that "The Kəbrä Nägäśt ... might have contributed, perhaps in a not significant way, to the extraordinary longevity or durability of the Solomonic Dynasty and to the equally inexplicable eclipse of the Zagwe and the Agäws" (Bayä, 1996, p. 43).

One of the major issues which have been neglected in the study of the Kəbrä Nägäśt is its impact on the medieval civilization of the Zagwe in the sphere of diplomacy, political stability, linguistics, genetics and agronomy, architectural, commercial developments. Pre-historic and botanical evidences revealed that the Zagwe have laid the foundation for a multi-national unitary state from lack of which the country suffered till the emergence of Gondärine period as the first capital for ethnic Amhara-Oromo joint kingdom (Gamst, 1984).

Hancock also corroborated the preceding view with his assertion as, "Both in terms of foreign and domestic policy, and also in terms of architectural expression and spiritual development, Lalibälla's reign had represented the zenith of the Zagwe Dynasty's power and achievements" (Hancock, 1997, p. 106).

They are also credited with preserving incalculable material and spiritual wealth from devastation by making Ethiopia neutral from the Crusades which ravaged the Eastern Mediterranean between 1095-1365 AD. (Lapiso Delebo, 1983, pp. 88-89). In the sphere of foreign trade, they are known to have initiated bilateral commercial and cultural links with neighboring countries like Jerusalem after a long period of isolation from the outer world.

The other cultural contribution pertains to the linguistic hybridization. Thus, according to Bender (1983), Ullendorff (1965), and Levine (1974), the Agäw have furnished Amharic with some linguistic characteristics as the latter is said to be built on a substratum of Agäw language. This is attributed to the fusion of both groups which resulted in the creation of a lingua franca or a Creole or proto-Amharic based on Cushomotic syntax (vb. Final) and Semitic lexicon. Bender also observed that "not only the present day Amhara are Semitized Agäw but also Amharic became the dominant language of Ethiopia by the accidents of history" (Bender, 1983, p. 48).

In terms of physiognomy or physical appearance, they have supplied the bulk of the Abyssinian population and determined their Somatic characteristics. Ullendorff asserted that it is the amalgam of Agäw with the immigrant Semitic elements which has given rise to the main Ethiopic type ethnically as well linguistically (Bender, 1983; Ullendorff, 1965; Levine, 1974). By the same token, Bender conjectured the identity construction and/or crisis from which both groups seem to have suffered:

I have frequently heard the statement that the Amhara are Semitized Agäws... The physical appearances of present day highland plateau Amhara are quite varied but certainly are in the range of what Semitized Agäw would presumably look like. (Bender, 1983, p. 48) 
Moreover, agronomists and botanists also posit that the Agäw have developed varieties of plants that reached them by diffusion from South Arabia and provided the major crops of the Ethiopic agricultural civilization (Taddesse, 1972, p. 57). In the same vein, James Quirin also corroborated this view with the following testimony:

In the Millennium before the rise of Aksum, the Agäw were among the most culturally creative people in Africa, credited with the development of the region as a centre of plant domestication, animal husbandry and plow agriculture. (Quirin, 1998, p. 197)

What is regrettable is the fact that most of these agricultural and horticultural contributions have not been sufficiently acknowledged and popularized. Paradoxically enough, in a country where ancient oriental and Greco-Roman civilization dating back to the BC's is enthusiastically pursued, the medieval history and contribution of its indigenous people is still shrouded in mystery. Thus, Taddesse reflected on this paradoxical attitude as follows:

The local people, although as much Christian and part of the Axumite cultural tradition as the peoples of Tigre and Amhara, had apparently preserved their linguistic identity and used Agäw outside the church. Essentially based on this linguistic difference, the Zagwe kings have been dismissed, on the dominant traditions of their political enemies as alien and impious groups of adventurers. This has long obscured what is perhaps the richest and most artistic period of Ethiopian civilization since the conversion of Ezana. (Taddesse, 1972, p. 57; Assefa, 2007, p. 38)

Moreover, the chronicles of those kings in spite of the conflicting figures have not been documented nor preserved. According to Pankhurst (1979), the lives of the Zagwe kings that have survived are those of Lalibälla and Na'akoto Lä'ab, the first existing in an MS of early XV and the second in an MS of XVII (p. 68).

Another aspect of obscurity is the conflicting figures of Zagwe kings and their corresponding chronology which varies from five to 11 kings spanning across 120 and 133 or more years respectively (Buxton, 1970; Taddesse, 1972). Moreover, their contribution to the survival and consolidation of Christianity is hardly acknowledged.

For instance, the fact that they had fought rebels in the south of the country and were powerful enough to preempt Egypt's imperial ambition of converting the country to Islam has not received a sufficient coverage in the Ethiopian historiography.

Virtually nothing or little is known or documented about their currency, national anthem (if any), and national flag (hierarchy, of military-command-chain or organizational set up, legal proceedings of their court and folklore). Even the rock-hewn churches at Lalibälla, the main town of the Zagwe kings and the grandeur of which is grudgingly acknowledged, are mentioned briefly as monuments constructed by foreign (Egyptian or Syrian) Christian exiles.

The Lalibälla monolithic churches, as art historians argued, were a result of a long period of political and social stability (at least over a century), a period that has been hardly surpassed in the country's history since the so-called "restoration" of the neo-Solomonic Dynasty in the late thirteenth century (Conti Rossini, 1928). The recent inauguration of another monolithic church named after Lalibälla (Lalibella II) carved by a handful of priests some kilometers away from Lasta is testimony enough to the indigenousness of these sculptures (Amhara National Regional Mass Media Agency, January 2018). Ironically enough, it is regrettable that even compatriots like Teklesadik Mäkuriya (1968) and Sergew Hable Śelasse (1972) maintained that these architectural pearls are the works of Syrian and Egyptians warriors as reflected in their writings. I wonder if 
there is a record in the annals of history which reveals a king who has ever assumed the role of a sculptor or a carpenter apart from his vision and patronage.

In spite of few registered treasures, nothing or little is known about the Zagwe contribution to Ethiopian civilization. The obscurity of this period is further aggravated by both subjective and objective factors. One of the subjective factors is the deliberate and concerted intrigue of the Solomonic elite and the clergy. According to Tekeste (2008) and Buxton (1970), two different ideological strands appear to have been in play in the reproduction and perpetuation of such manifestly discriminatory historical writing. The first ideological assault certainly originated from the Solomonic rulers and their chroniclers (Amhara and Təgrean monks) who discovered the rhetoric of written chronicles to present themselves in a better light than the Zagwe Dynasty would appear.

The second ideological strand was that represented by Conti Rossini, whose writing in the early decades of this century did not hesitate to stress and emphasize the foreign (south Arabian, Syrian, Egyptian) footprints in nearly every dimension of Ethiopian civilization (Buxton, 1970). On the other hand, the architectural pearls of the Zagwe still retain their force as authoritative sources, at least among historian.

For instance, Buxton remarked that the Zagwe kings attained a degree of stability and technical advancement seldom equaled in Abyssinian history (Buxton, 1970). Thus, in spite of its width and breadth, the contribution of Zagwe period to Abyssinian civilization has not been sufficiently popularized for one reason or another. The situation is reminiscent of the medieval period in the history of Western Europe during which ancient Greek manuscripts were destroyed due to Christian hostility to "pagan art". The problem was further compounded by the prolonged reign of the Solomonic era which aggravated the eclipse of the Zagwe civilization.

What happened to the Agäws who were scattered across Eritrea, Begemədər, Tigray, and Šowa? What is the reason for the disruption of Agäw civilization? How and why Agäws were Balkanized into island-like survivals all over north-western Ethiopia and Eritrea? Was Ethiopian cultural historiography impartial or discriminatory? Thus, Murdock resentfully observed that "The lack of information is doubly regrettable since all indications point to the Agäw as one of the most creative peoples on the entire continent" (Murdock, 1949, p. 182).

\section{Conclusion}

The anti-Zagwe propaganda warfare was waged with the patronage of the clergy who were instrumental in the restoration of the so-called Solomonic Dynasty in 1270. In order to invest an aura of legitimacy to the throne, they had to launch propaganda warfare against the Zagwe via the Kabrä Nàgàśt which is said to be their political gospel. The Kəbrä Nägäśt had captured the attention of both compatriot and expatriate scholars who have reinterpreted it to their discretion and in the context of the restoration process.

However, their observations and value judgments seem to be biased for the so-called Solomonic Dynasty, thus undermining the impact of this political "gospel" on the Zagwe civilization.

The foregoing observations would hopefully provide a staple for calibrating the research gap between the existing corpus of research out put on the Kəbrä Nägàśt and what has been shrouded in mystery about the Agäw civilization. The latter is presumably attributed to the obsession of scholars with the face value of Kəbrä Nägäśt when its attendant impact on the cultural and material achievements of the Zagwe period should have received a proper critical attention or recognition. 
This gap on the critical reception of Kəbrà Nägàśt calls for a renewed commitment on the part of linguists, sociologists, agronomists, philologists, folklorists, historians, and political analysts with a view to reconstructing and popularizing the multi-dimensional contributions of the Agäw people to Ethiopian civilization without prejudice to the glorious era of the neo-Solomonic Dynasty.

\section{References}

Appleyard, D. L. (1988). The Agäw languages: A comparative morphological perspective. In T. Beyene (Ed.), Proceedings of the Eighth international conference on Ethiopian studies (pp. 581-592). Addis Ababa: IES.

Assefa, E. (2007). Ethiopia: Yähəzboč səbtərna yagäzazoč awäqaqür ačər tarik. Addis Ababa: Bärəhanəna Sälam Printing Press. Bayä, F. (1996). Questions about the Kabrä Nägäśt. Addis Ababa: Aläm Printers.

Bender, M. L. (1983). The origin of Amharic. Journal of Institute of Language Studies, 1, 42-48.

Bezold, K. (1928). Storia d' Ethiopie. Milano.

Budge, S. W. (1922). The queen of Saba and her only son Menyelek. London: Martin Hopkins and Company Ltd.

Buxton, D. (1970). The Abyssinians. London: Thames and Hudson.

Conti Rossini, C. (1928). Storia d'Etiopia. Bergamo: Instituto di Arti Grafiche.

Dästa Täklä-Wold. (1992). Haddis yamarəňa mäzgäbä qalat. Addis Ababa: Artistic Printing Press.

Fəqre, T. (1993). Amhara contribution to Ethiopian civilization. Ethiopian Review, 3(4), 1-5.

Fiqəre, T. (2008 E.C). YäOromona yäAmara зwuntäñaw yäzar mənĉ. Addis Ababa: Nebadan Publications.

Gädlä Täklä Haymanot. (1946). Addis Ababa: Tənsae Zä Guba'e Publishing House.

Gamst, F. C. (1984). The Quəmant: A pagan Hebraic peasantry of Ethiopia. Illinois: Waveland Press Inc.

Hancock, G. (1997). The sign and the seal. London: Cox \& Wyman Co.

Hetzron, R. (1969). The verbal system of southern Agäw. Berkeley: University of California Press.

Hubbard, D. A. (1956). The literary sources of the Kəbrä Nägäśt (Doctor's thesis, St. Andrews University).

Jack, F. (1996). Review of Kəbrä Nägäśt. In E. A. Wallis Budge \& F. M. Brooks (Eds.), International Journal of African Historical Studies, 32(1), 192.

Kasse, K. (1972). Bäwag Säqoțaw Agäwňa yäsəmočəna yäsəmäsäloč mə'ladawi sərə’at (Unpublished B.A. thesis, Addis Ababa University).

Lapiso Delebo, G. (1983). Yä Ethiopia räžəm yahəzəbəna yä mänəgəsət tarik. Addis Ababa: Commercial Printing Press.

Levine, D. N. (1973). Mənilək and Oedipus: Further observations on the Ethiopian national epic. In H. Marcus (Ed.), Proceedings of The First United States Conference on Ethiopian Studies (pp. 11-24). East Lansing: Michigan Universty.

Levine, D. N. (1974). Greater Ethiopia: The evolution of a multiethnic society. Chicago: The University of Chicago Press.

Levine, D. N. (1975). Menelik and Oedipus: Further observations on the Ethiopian national epic. In H. Marcus (Ed.), Proceedings of The First United States Conference on Ethiopian studies (pp. 11-24). East Lansing: Michigan University.

Murdock, G. P. (1949). Africa: Its people and their culture history. New York: McGraw-Hill.

Pankhurst, R. (1979). Historical geography of Ethiopia: First century A.D.-1704. Addis Ababa: Bärəhanəna Sälam Printing Press.

Piovanelli, P. (2013). The apocryphal legitimation of a "Solomonic" Dynasty in the Kəbrä Nägäśt—A reappraisal. Aethiopica: International Journal of Ethiopian and Eritrean Studies, 16, 7-44.

Prouty, C., \& Rosenfeld, E. (1994). Historical dictionary of Ethiopia and Eritrea. London: Scarecrow Press.

Quirin, J. (1998). Caste and class in the historical north-west Ethiopia: The Beta-Israel (Falasha) and Komant, $1300-1900$. Journal of African History, 39, 195-220.

Rank, O. (1959). The myth of the birth of a hero: A psychological interpretation of mythology. New York: Random House Inc.

Roth, J. (1905). Akademic der winssenshaften. Munchen: Verlag der k.

Sergew , G. (1994). Kabrä Nägäśt. Addis Ababa: Commercial Printing Press.

Sergew, H. Ś. (1972a). Ancient and medieval Ethiopian history to 1270. Addis Ababa: United Printers.

Sergew, H. Ś. (1972b). The problem of Godwit. Journal of Ethiopian Studies, 1(10), 112-124.

Shahid, I. (1976). The Kabrä Nägäśt in the light of recent research. Paris: Le Meson.

Taddesse, T. (1972). Church and state in Ethiopia, 1270-1527. London: Oxford University Press.

Taddesse, T. (1988). The process of ethnic interaction and integration in Ethiopian history: The case of the Agäw. The Journal of African History (Special Issue), 29(1), 5-18. Addis Ababa: Institute of Ethiopian Studies. 
Taye, G. (1946). Ye Ethiopia haze tarik. AA: Bərhanəna Sälam Printing Press.

Tekeste, N. (2008). The Zague period re-interpreted: The post-Axumite Ethiopian urban culture. Retrieved from http://www.arkelogi.uuafr/projects/BOOK/negash.pdf

Teklesadik, M. (1968). Axum and Zagwe. Addis Ababa: Ministry of Education.

Trimingham, J. S. (1952). Islam in Ethiopia. London: Oxford University Press.

Ullendorff, E. (1955). The Semitic languages of Ethiopia: A comparative phonology. London: Taylor's Foreign Press.

Ullendorff, E. (1965). The Ethiopians: Introduction to country and people. London: Oxford University Press.

Ullendorff, E. (1968). Ethiopia and the Bible. London: Taylor's Foreign Press.

Yä Ethiopia həgä mänəgəst (yätäŝaŝaslä). (1948). The constitution of Ethiopia, 1955 (Revised). Addis Ababa: Bərhanəna Sälam Printing Press.

Yonas, A. (1995). Narrating Ethiopia: Panorama of national imaginary (PhD dissertation, University of California). 